\title{
PENGARUH PELATIHAN METODE SIMULASI TERHADAP PERILAKU KADER DALAM UPAYA PEMBERIAN ASI EKSKLUSIF
}

\author{
Jumiyati \\ Politeknik Kesehatan Kementerian Kesehatan Bengkulu, Jurusan Gizi, \\ Jalan Indragiri Nomor 03 Padang Harapan Kota Bengkulu \\ yatijumi70@yahoo.co.id
}

\begin{abstract}
Exclusive breastfeeding in Indonesia fluctuated and showed a tendency to decrease from the age of zero months to five months. The low coverage of exclusive breastfeeding is influenced by not maximal yet educational activities and fostering optimal breastfeeding support group. Breastfeeding support group can involve cadre by increasing knowledge, skills and training. The purpose of the study to determine the effect of training with simulation methods of behavior of cadres to effort exclusive breastfeeding. This research is a quasi experimental with a non- randomized control group pretest and post test. the ppopulation are 105 cadres with 60 samples. the Measurement of knowledge and skills done before and after the study. The results of the study can improve the of cadres knowledge about breastfeeding in the treatment group was higher than the control group with $p=0.001$. so also skill cadre enhancement in the treatment group was higher than the control group with $p=0.001$ (Training with simulation methods and administration modules can improve cadre behavior (knowledge and skills)
\end{abstract}

Keywords: Simulation Training methods and modules, behavioral cadres.

\begin{abstract}
Abstrak : Pemberian ASI eksklusif di Indonesia berfluktuasi dan menunjukan kecenderungan menurun dari usia nol bulan sampai lima bulan. Rendahnya cakupan ASI eksklusif dipengaruhi oleh belum maksimalnya kegiatan edukasi dan belum optimalnya membina kelompok pendukung ASI. kelompok pendukung ASI dapat melibatkan peran kader dengan cara menambah pengetahuan, keterampilan dan pelatihan. Tujuan penelitian untuk mengetahui pengaruh pelatihan metode simulasi terhadap prilaku kader dalam upaya pemberian ASI ekkslisif. Jenis penelitian ini adalah quasi experimental dengan rancangan Non Randomized control group pretest and postest design. Populasi 105 kader dan sampel 60 kader. Pengukuran pengetahuan dan keterampilan sebelum dan sesudah perlakuan dengan uji beda rata-rata. Hasil penelitian dengan pelatihan dapat meningkatkan pengetahuan kader tentang ASI pada kelompok perlakuan lebih tinggi dibandingkan kelompok kontrol dengan nilai $p=0,001$. Begitu juga ketrampilan kader pada kelompok perlakuan peningkatan lebih tinggi dibandingkan kelompok kontrol dengan nilai $p=0,002$ Pelatihan dengan metode simulasi dan pemberian modul dapat meningkatkan prilaku (pengetahuan dan keterampilan) kader.
\end{abstract}

Kata kunci: Pelatihan, metode Simulasi dan modul, perilaku kader.

Pemberian ASI eksklusif sebaiknya diberikan ASI saja tanpa makanan tambahan sampai bayi berusia 6 bulan, karena semua zat gizi yang dibutuhkan sampai umur tersebut dapat dipenuhi dari ASI saja. ASI merupakan nutrisi yang memiliki kualitas dan kuantitas terbaik saat masa pertumbuhan 0-6 bulan (Wirjatmadi, 2012). Pemberian ASI sangat penting bagi tumbuh kembang yang optimal baik fisik maupun mental dan kecerdasan bayi (pudjiadi, 2005).
Masih rendahnya cakupan ASI eksklusif dipengaruhi beberapa hal, terutama masih sangat terbatasnya tenaga konselor ASI, belum maksimalnya kegiatan edukasi, sosialisasi, advokasi dan kampanye terkait pemberian ASI, masih rendahnya ketersediaan sarana dan prasarana KIE ASI dan belum optimalnya membina kelompok pendukung ASI (Astika, 2012).

Salah satu kelompok pendukung ASI di masyarakat dapat melibatkan peran kader de- 
ngan cara mengadakan pelatihan untuk menambah pengetahuan dan keterampilan kader. Pelatihan dengan metode simulasi kader dapat meniru, memeragakan ulang segala sesuatu yang berkaitan dengan materi yang disampaikan. Metode ini bertujuan untuk melatih dan memahami konsep atau prinsip dari pendidikan yang disampaikan sehingga dapat memecahkan masalah yang dihadapi (Depkes RI, 2007).

Selama ini kader lebih sering menjadi pelaksana kegiatan saja, maka perlunya menyelenggarakan pelatihan menggunakan modul yang sederhana yang sesuai dengan perkembangan keadaan dan kebijakankebijakan yang baru, pelatihan bagi kader posyandu sebagai refresing dan menambah pengetahuan dan keterampilan kader posyandu (Depkes RI, 2005).

Hasil penelitian yang dilakukan Sudarmanto, didapatkan bahwa ada pengaruh pelatihan dengan menggunakan modul pendamping KMS terhadap peningkatan pengetahuan kader dan ketepatan kader dalam interpretasi hasil penimbangan anak di posyandu oleh sebab itu diperlukan upaya pemberdayaan kader (Sudarmanto). Begitu juga hasil penelitian Ferry menunjukan bahwa ada pengaruh pendampingan bidan terhadap keberhasilan pemberian ASI eksklusif setelah mendapat pendampingan (Ferry, 2011).

Secara nasional, cakupan pemberian ASI eksklusif di Indonesia berluktuasi dan menunjukan kecendrungan menurun. Laporan susenas tercatat cakupan pemberian ASI eksklusif pada bayi 6-6 bulan turun dari $34,3 \%$ (2009) menjadi 33,6\% (2010), demikian juga laporan profil Dinas Kesehatan Provinsi Bengkulu Tahun 2011, jumlah bayi yang berumur 0-6 bulan 34.659 bayi dari 10 kabupaten yang tidak ASI eksklusif 16.650 (48\%) dan ASI eksklusif 16.615 (52\%). Sedangkan data profil Dinas Kesehatan Kota Bengkulu jumlah bayi 1.478 yang mendapat ASI eksklusif $46,5 \%$ dan yang tidak ASI eksklusif 53,5\%. Dari 20 Puskesmas yang ada di Kota Bengkulu, cakupan pemberian ASI eksklusif di Puskesmas Sukamerindu yaitu 40,3\%. Berdasarkan data tersebut dapat disimpulkan di Propinsi Bengkulu untuk cakupan pemberian ASI eksklusif masih dibawah target nasional (Dinkes Bengkulu, 2011).

Rendahnya cakupan ASI eksklusif di Indonesia menjadi pemicu ketidak berhasilan program KADARZI (Depkes RI, 2007). Berbagai sebab antara lain kurangnya pengetahuan ibu akan pentingnya ASI bagi bayi, pemberian makanan yang terlalu dini, meningkatnya promosi susu formula untuk bayi dan kurangnya dukungan dari lingkungan dan praktisi kesehatan (Soetjiningsih,1989). Maka diperlukannya pendampingan dengan cara memberikan perhatian, memotivasi, memberikan solusi dan memberikan nasehat. Pendampingan dilakukan oleh kader yang sudah terlatih agar kader dapat memotivasi ibu menyusui, biasanya setiap kota atau kabupaten mempunyai kriteria sendiri untuk kader pendampingnya (Depkes RI, 2005).

Penelitian ini bertujuan untuk mengetahui pengaruh pelatihan dengan metode simulasi dan pemberian modul terhadap peningkatan pengetahuan dan keterampilan kader dalam upaya pemberian ASI eksklusif di Kota Bengkulu. Hasil penelitian ini diharapkan memberikan informasi dan masukan bagi kader dalam memberikan pelayanan terutama peningkatan kerja kader dalam upaya pemberian ASI eksklusif dan menambah pengetahuan dan keterampilan kader tentang ASI eksklusif serta bekal untuk melakukan pendamping kepada ibu yang menyusui.

\section{BAHAN DAN CARA KERJA}

Jenis penelitian adalah quasi experimental dengan rancangan penelitian Non Randomized with pretest and postest group, dilaksanakan bulan Januari 2013. Intervensi berupa pelatihan dengan metode simulasi dan pemberian modul yang telah dikembangkan dan melalui uji validitas. Uji coba modul pendampingan dilaksanakan dengan cara Focus Group Discussion (FGD) pada kader sebanyak 20 kader yang tidak menjadi sampel penelitian. Uji validitas menggunakan korelasi product moment dan pearon. Uji Reliabilitas menggunakan analisa Alpha cronbach $>0,60$. Populasi adalah seluruh kader posyandu yang ada di Puskesmas Su- 
kamerindu dan Puskesmas Sidomulyo Kota Bengkulu berjumlah 105 kader. Sampel sebanyak 30 kelompok intervensi dan 30 kelompok kontrol, dipilih secara purposive sampling yaitu dengan pertimbangan tertentu yang dibuat oleh peneliti, berdasarkan ciri atau sifat populasi yang sudah diketahui sebelumnya. Kriteria sampel yaitu kader yang masih aktif, pendidikan minimal SMP, dan belum pernah mengikuti pelatihan. Hasil pre dan post test diukur dengan kuesioner untuk mengukur pengetahuan kader, daftar tilik sebagai alat ukur keterampilan kader. Metode simulasi dan pemberian modul sebagai panduan saat menyampaikan materi. Post test dilakukan langsung setelah pelatihan. Analisis bivariat menggunakan uji statistik paired t-test dan independent sample t-test (paramterik) dan uji Wilcoxon Signed Ranks Test dan uji Mann Whitney Test (Non Parametrik).

HASIL

Tabel 1 Karakteristik Kader Kelompok Perlakuan dan Kelompok Kontrol

\begin{tabular}{|c|c|c|c|c|c|}
\hline \multirow{2}{*}{$\begin{array}{c}\text { Karakteristik } \\
\text { Kader }\end{array}$} & \multicolumn{2}{|c|}{ Perlakuan } & \multicolumn{2}{|c|}{ Kontrol } & \multirow[t]{2}{*}{$p$} \\
\hline & $\mathbf{f}$ & $\%$ & f & $\%$ & \\
\hline \multicolumn{6}{|l|}{ Pendidikan } \\
\hline SMP & 6 & 20 & 6 & 20 & 0,801 \\
\hline SLTA & 17 & 56,7 & 19 & 63,3 & \\
\hline PT & 7 & 23,3 & 5 & 16,7 & \\
\hline \multicolumn{6}{|l|}{ Umur } \\
\hline$<35$ Tahun & 6 & 20 & 1 & 3,3 & 0,020 \\
\hline 35 - 45 Tahun & 12 & 40 & 7 & 23,3 & \\
\hline$>45$ Tahun & 12 & 40 & 22 & 73,3 & \\
\hline \multicolumn{6}{|l|}{ Lama Menjadi Kader } \\
\hline$<10$ Tahun & 12 & 40 & 17 & 56,7 & 0,282 \\
\hline 10 - 15 Tahun & 10 & 33,3 & 5 & 16,7 & \\
\hline$>15$ Tahun & 8 & 26,7 & 8 & 26,7 & \\
\hline
\end{tabular}

Tabel 1 menunjukkan sebagian besar dari kelompok perlakuan berpendidikan SLTA $(56,7 \%)$, sebagian besar umur kader antara 35-45 tahun (40\%), lama menjadi kader antara $<10$ tahun yaitu $(40 \%)$ dan umur kader sebagian besar > $45(73,3 \%)$, lama menjadi kader $<10$ tahun $(56,7 \%)$ dan sumber informasi yang didapatkan sebagian besar dari media massa (60\%). Dari hasil uji statistik tidak ada perbedaan karakteristik pendidikan, lama menjadi kader dan sumber informasi antara kelompok perlakuan dan kelompok kontrol $(p>0,05)$, tetapi untuk umur ada perbedaan $(p<0,05)$.

Tabel 2 Deskripsi Tingkat Pengetahuan dan Keterampilan Kader Sebelum perlakuan pada masingmasing kelompok

\begin{tabular}{lcccc}
\hline \multicolumn{1}{c}{ Variabel } & Min & Max & Mean \pm SD & $\boldsymbol{p}$ \\
\hline $\begin{array}{l}\text { Pengetahuan } \\
\text { Kelompok }\end{array}$ & 58 & 74 & $66,7 \pm 4,08$ & $0,107^{\mathrm{e}}$ \\
$\begin{array}{l}\text { Perlakuan } \\
\text { Kelompok }\end{array}$ & 58 & 76 & $66,7 \pm 5,43$ & \\
$\begin{array}{l}\text { Kontrol } \\
\text { Keterampilan }\end{array}$ & & & & \\
$\begin{array}{l}\text { Kelompok } \\
\text { Perlakuan }\end{array}$ & 62 & 77 & $67,0 \pm 3,56$ & $0,250^{\mathrm{e}}$ \\
$\begin{array}{l}\text { Kelompok } \\
\text { Kontrol }\end{array}$ & 67 & 75 & $65,7 \pm 5,10$ & \\
\hline \multicolumn{1}{c}{$e=$ Independent t-test } & & & \\
\end{tabular}

Dari tabel 2 didapatkan rata-rata tingkat pengetahuan kader yang diberi perlakuan adalah 64,67, kelompok kontrol rata-rata tingkat pengetahuannya 66,70 dengan nilai $\rho=0,107$. Rata-rata keterampilan kader yang diberi perlakuan adalah 67,05, keterampilan kader pada kelompok kontrol yaitu 65,73 dengan nilai $\rho=0,250$.

Tabel 3 Perbedaan Skor Pengetahuan dan keterampilan Sebelum dan Sesudah Pelatihan pada Kelompok Perlakuan dan Kelompok Kontrol

\begin{tabular}{|c|c|c|c|}
\hline \multirow[t]{2}{*}{ Variabel } & \multicolumn{2}{|c|}{ Rata-Rata } & \multirow[t]{2}{*}{$p$} \\
\hline & Sebelum & Sesudah & \\
\hline \multicolumn{4}{|l|}{ Pengetahuan } \\
\hline Kelompok & $64,7^{\mathrm{a}} \pm 4,08$ & $74,6^{\mathrm{a}} \pm 6,57$ & $0,001^{\mathrm{c}}$ \\
\hline \multicolumn{4}{|l|}{ Perlakuan } \\
\hline Kelompok & $66,7^{\mathrm{a}} \pm 5,43$ & $69,9^{\mathrm{a}} \pm 5,57$ & $0,004^{\mathrm{c}}$ \\
\hline \multicolumn{4}{|l|}{ Kontrol } \\
\hline \multicolumn{4}{|l|}{ Keterampilan } \\
\hline Kelompok & $67,0^{\mathrm{a}} \pm 3,56$ & $71,6^{\mathrm{a}} \pm 3,56$ & $0,001^{\mathrm{c}}$ \\
\hline \multicolumn{4}{|l|}{ Perlakuan } \\
\hline Kelompok & $65,7^{\mathrm{a}} \pm 5,10$ & $67,7^{\mathrm{a}} \pm 4,69$ & $0,005^{\mathrm{c}}$ \\
\hline \multicolumn{4}{|l|}{ Kontrol } \\
\hline \multicolumn{4}{|c|}{ ket: $a=$ Rata-rata \pm Standar Deviasi } \\
\hline \multicolumn{4}{|c|}{$b=$ Median \pm Standar Deviasi } \\
\hline \multicolumn{4}{|c|}{$c=$ Paired t test } \\
\hline
\end{tabular}

Tabel 3 didapatkan rata-rata pengetahuan kader kelompok perlakuan pre-test adalah 64,67 dan post-test adalah 74,65 dengan nilai $\rho=0,001$, keterampilan kader pre-testt 
pada kelompok perlakuan adalah 67,05 post-test adalah 71,60 dengan nilai $\rho=0,001$. Hasil rata-rata pengetahuan kader pre-test pada kelompok kontrol adalah 66,70 posttest pengetahuan kader adalah 69,97 dengan nilai $\rho=0,004$, rata-rata keterampilan kader pre-test adalah 65,73 post-test adalah 67,73 dengan nilai $\rho=0,005$.

Tabel 4 Perubahan Skor Pengetahuan dan Keterampilan Kader Antara Kelompok Perlakuan dan Kelompok Kontrol

\begin{tabular}{ccccc}
\hline $\begin{array}{c}\text { Variabel dan } \\
\text { Kelompok }\end{array}$ & N & $\begin{array}{c}\text { Rata- } \\
\text { Rata }\end{array}$ & $\begin{array}{c}\text { Median } \\
\mathbf{\pm S D}\end{array}$ & $\boldsymbol{\rho}$ \\
\hline $\begin{array}{c}\text { Pengetahuan } \\
\text { Perlakuan }\end{array}$ & 30 & 9,63 & $9,50 \pm 3,00$ & $0,001^{\mathrm{f}}$ \\
$\begin{array}{c}\text { Kontrol } \\
\text { Keterampilan }\end{array}$ & 30 & 3,27 & $3,82 \pm 2,51$ & \\
Perlakuan & 30 & 4,55 & $3,80 \pm 2,00$ & $0,002^{\mathrm{f}}$ \\
Kontrol & 30 & 2,00 & $1,83 \pm 2,33$ & \\
\hline$f=$ Mann-Whitney & & &
\end{tabular}

Tabel 4 menunjukkan ada peningkatan nilai median pengetahuan dan keterampilan sebelum dan sesudah perlakuan, Kelompok perlakuan nilai median pengetahuan adalah 9,50 dan kelompok kontrol pengetahuan 3,82 dengan nilai $\rho=0,001$. Sedangkan untuk keterampilan kelompok perlakuan adalah 3,80 untuk kelompok kontrol keterampilan 2,00 dengan nilaip $\rho=0,002$.

\section{PEMBAHASAN}

\section{Perbedaan Tingkat Pengetahuan Kader Anta- ra Kelompok Perlakuan Dengan Kelompok Kontrol Sebelum dan Setelah Pelatihan}

Hasil penelitian menunjukan tidak terdapat perbedaan yang bermakna kedua kelompok baik pengetahuan dan keterampilan kader sebelum perlakuan, hal ini menunjukan kader baru ditahap tahu karena kader meng-ingat kembali materi yang telah dipelajari sebelumnya atau rangsangan yang telah diterima (Notoatmodjo,2003).

Uji beda yang dilakukan kedua kelompok terjadi perbedaan yang bermakna, kelompok perlakuan peningkatan nilainya lebih besar di bandingkan kelompok kontrol. Hal ini disebabkan kelompok perlakuan diberi pelatihan dengan metode simulasi dan pemberian modul serta tanya jawab. Menurut pe- nelitian para ahli, indra yang paling banyak menyalurkan pengetahuan ke dalam otak adalah mata (kurang lebih 75-87\%), sedangkan 13-25\% lainnya tersalur melalui indra yang lain (Notoadmodjo,2003a). Hasil ini sejalan dengan penelitian terdahulu seperti penelitian Goraahe, menjelaskan bahwa adanya perbedaan peningkatan pengetahuan kader sebelum dan sesudah pelatihan dalam menilai kurva pertumbuhan balita (Goraahe, 2009).

Pelatihan yang dilakukan merupakan salah satu kegiatan yang penting agar kader mau dan mampu berperan serta dalam melaksanakan kegiatan posyandu atau program yang ada di puskesmas. Oleh karena itu pengetahuan dan keterampilan kader harus disesuaikan dengan tugas mereka dalam melaksanakan pendampingan atau penyuluhan (Depkes RI, 2005). Informasi atau pengetahuan yang sering dan berulang dapat meningkatkan pengetahuan seseorang dan seseorang memperoleh pengetahuan berasal dari pengalaman sendiri atau pengalaman orang lain (Notoadmdjo, 2003).

Berbeda dengan pengetahuan kader yang tidak mendapat perlakuan tidak menunjukan peningkatan yang terlalu, hal ini disebabkan pada saat proses penelitian terjadi komunikasi satu arah di mana materi yang diperoleh kader hanya bersumber pengalaman dan media massa, bukan berasal dari tenaga kesehatan atau fasilitator langsung, sehingga kurang mampu menggali sejauh mana pengetahuan kader.

Pengetahuan seseorang sangat dipengaruhi oleh faktor pendidikan, pekerjaan, pengalaman dan informasi yang diterima oleh seseorang yang berupa pesan-pesan kesehatan baik melalui media cetak atau elektronik dan pengetahuan merupakan peran yang sangat penting untuk terbentuknya tindakan sesorang, berdasarkan pengalaman dan penelitian ternyata perilaku yang didasari oleh pengetahuan akan lebih langgeng dari pada tidak didasari pengetahuan (Notoatmodjo, 2003). 


\section{Perbedaan Keterampilan Kader Antara Ke- lompok Perlakuan Dengan Kelompok Kon- trol Sebelum dan Setelah Pelatihan}

Keterampilan adalah suatu kemampuan dalam melaksanakan tugas atau pekerjaan dengan menggunakan anggota badan dan peralatan yang tersedia, serta mampu memotivasi dan bekerjasama dengan orang lain. Keterampilan kader yang dimaksudkan dalam penelitian ini adalah kemampuan seseorang kader dalam menjelaskan dan mengajarkan persiapan pemberian ASI, cara pemberian ASI, cara memerah ASI dan cara penyimpanan ASI (Hida, 2011).

Keterampilan kader sebelum perlakukan dalam upaya pemberian ASI eksklusif menunjukan tidak ada perbedaan antara kedua kelompok. Setelah dilakukan pelatihan dengan pedoman observasi terhadap keterampilan kader, terdapat perubahan nilai ratarata keterampilan kader meningkat disbandingkan kelompok kontrol. Perbedaan ini disebabkan karena metode yang digunakan dalam pelatihan ini adalah simulasi dan pemberian modul sedangkan pada kelompok kontrol tidak diberi perlakuan. Dengan dilakukanya simulasi atau praktek langsung akan lebih mempermudah cara penyampaian informasi yang dapat meningkatkan pengetahuan dan keterampilan kader (Notoatmodjo, 2007).

Hasil ini sejalan dengan penelitian terdahulu seperti penelitian Suharti adanya pengaruh keterampilan sebelum dan setelah dilakukan pelatihan teknik menyusui pada ibu nifas (suharti, 2008). Begitu juga dengan hasil Penelitian Inong dengan pelatihan terjadi peningkatan pengetahuan kader tentang program kadarzi, kelancaran kegiatan program kadarzi sangat erat kaitannya dengan keaktifan kader pendamping sebagai pelaksanaannya di masyarakat (Inong,2005).

Peningkatan memang tidak begitu berbeda pada kedua kelompok, hal ini disebabkan pengalaman dari semua responden adalah sama. Dalam kegiatan pelatihan ini hanya memberikan penguatan terhadap apa yang sudah dimiliki para kader, terkait dengan materi ASI, sebenarnya bukan materi yang baru karena sudah banyak media massa yang menggulas materi ASI. Meskipun sudah banyak media massa yang menayangkan tentang segala sesuatu yang terkait dengan ASI eksklusif, tetapi kadang-kadang kader atau masyarakat masih membutuhkan penguat dari orang-orang yang ada di sekitarnya untuk merubah perilaku.

Berbeda dengan kelompok kontrol yang menunjukan tidak ada perbedaan keterampilan kader dalam upaya pemberian ASI eksklusif, hal ini disebabkan karena kader tidak medapat pelatihan sehingga pengetahuannya tentang ASI hanya didapat dari membaca dan mendengar dari orang lain. Kader lebih banyak belajar dari pengalamannya dalam praktek pemberian ASI. Hal ini sesuai dengan pernyataan Azwar menyatakan bahwa orang lain merupakan salah satu diantara komponen sosial yang ikut mempengaruhui sikap atau perilaku (Notoatmodjo 2003).

\section{Pengaruh Pelatihan Antara Kelompok Perla- kuan Dan Kelompok Kontrol}

Hasil penelitian menunjukan adanya perbedaan yang bermakna kedua kelompok, rata-rata pengetahuan post-test pada kelompok per-lakuan lebih tinggi dari pada kelompok kontrol. Hasil penelitian ini sejalan dengan penelitian terdahulu seperti penelitian Sri terjadi peningkatan pengetahuan gizi ibu sebesar 25.5 poin setelah pendampingan (Sri, 2009). Keadaan ini memberikan gambaran bahwa pelatihan dengan metode simulasi dan penggunakan modul sangat bermanfaat bagi peningkatan pengetahuan, karena modul merupakan bahan ajar cetak yang dirancang untuk dapat dipelajari secara mandiri oleh peserta pembelajaran. Modul disebut juga media untuk belajar mandiri karena di dalamnya telah dilengkapi petunjuk untuk belajar sendiri (Departemen Pendidikan Nasional, 2001).

Keterampilan kader menunjukkan bahwa pada kelompok perlakuan dan kelompok kontrol mengalami kenaikan secara bermakna. Hasil pengukuran terhadap rata-rata kenaikan nilai keterampilan menunjukkan bahwa nilai kelompok perlakuan lebih tinggi di- 
bandingkan kelompok kontrol. Pada kelompok perlakuan menggunakan metode simulasi yang mana metode ini dapat mengatasi permasalahan yang dihadapi dan dapat meningkatkan akselerasi pemikiran dan perasaan sikap dan psikomotorik pembelajaran (Jennifer, 2008). Kelompok kontrol kurang menguntungkan karena kader tidak memungkinkan untuk berkomunikasi dan menanyakan hal-hal yang kurang dipahaminya. Metode belajar yang lebih banyak memberikan keuntungan adalah metode belajar dengan komunikasi dua arah antara pengajar dan peserta latih, dengan demikian peserta dapat dengan lebih mudah memahami materi yang diberikan (Liliweri, 2011).

Hasil ini sejalan dengan penelitian terdahulu seperti penelitian yang dilakukan Edy peningkatan pada skor keterampilan terjadi sebesar 4,6\% setelah dievaluasi 2 minggu kemudian (Edy, 2007). Begitu juga dengan penelitian Hida, menunjukkan ada perbedaan keterampilan kader dalam pengukuran antropometri sebelum dan sesudah pelatihan (Hilda, 2011).

Peningkatan rata-rata sekor pengetahuan dan keterampilan kader lebih tinggi pada kelompok perlakuan, karena kelompok tersebut lebih banyak indra yang digunakan, yaitu

\section{DAFTAR RUJUKAN}

Astika, 2012. Kesehatan Ibu Dan Anak Dalam Mellenium Development Goals (MDGS), Nuha Medika

Departemen Pendidikan Nasional, 2001. Teknik Belajar Dengan menggunakan Modul, Jakarta

Depkes RI, 2005. Panduan Pelatihan Kader Posyandu, Jakarta

Petunjuk Praktis Bagi Kader Dalam Mendampingi Ibu Menyusui, Jakarta

Depkes RI, 2007. Pedoman Strategi Kie Keluarga Sadar Gizi. Jakarta: Dirjen Bina Kesehatan Masyarakat Direktorat Bina Gizi Masyarakat,

Dinas Kesehatan Bengkulu, 2011. Propil Dinas Kesehatan 2011, Bengkulu

Edy, Laksmi dkk, 2007. Pengaruh pelatihan Dengan Metode Belajar Berdasarkan Masalah (BBM) dalam Kegiatan Kader Posyandu; Studi di Kecamatan Tempuran Kabupaten Magelang. Media Medika Indonesia. Volume 42, No 3.

Ferry, 2011. Pengaruh Pendampingan Bidan Terhadap Keberhasilan Pemberian ASI penglihatan pendengaran dan peraba. Semakin banyak indra yang digunakan untuk menerima sesuatu maka semakin banyak dan semakin jelas pengetahuan yang diperoleh (Notoadmodjo, 2007).

\section{KESIMPULAN}

Berdasarkan hasil penelitian ini dapat diambil suatau kesimpulan sebagai berikut: hasil penelitian menunjukan terjadi peningkatan pada kelompok perlakuan setelah diberi intervensi skor pengetahuan yaitu 9,63 dan keterampilan kader yaitu 4,55, karena kelompok ini diberi pelatihan dengan metode simulasi dan pemberian modulu. Sedangkan untuk kelompok kontrol terjadi peningkatan pengetahuan sebesar 3,27 dan keterampilan kader yaitu 2,00, peningkatan ini tidak terlalu karena kelompok kontrol tidak diberi perlakuan, pengetahuan dan keterampilan kader hanya berdasarkan pengalaman.

Disarankan perlunya pelatihan seluruh kader agar dapat menambah pengetahuan dan keterampilan kader, sehingga kader dapat melakukan pendampingan dan penyuluhan pada saat kegiatan di posyandu atau di masyarakat. Sebaiknya evaluasi dilakukan lebih dari satu kali sehingga pengetahuan dan keterampilan kader benar-benar terukur.

Eksklusif Di Kota Pasuruan, Semarang: Universitas Diponegoro

Goraahe, 2009. Perbedaan Pengetahuan Tentang Peran Kader Dan Kemampuan Dalam Menilai Kurva Pertumbuhan Balita Sebelum Dan Sesudah Pelatihan Partisifatif, , www.fkm.undip.ac.id/data/index.php

Hida, 2011. Keterampilan Kader Posyandu Sebelum dan Sesudah Pelatihan, Vol 7, no.1 Tahun 2011. http://jurnal unnes.ac.id/index php/kesmas.

Inong d, 2005. Pemberdayaan Kader Posyandu Melalui Penerapan Metode Konseling Gizi Dalam Upaya Meningkatkan Kualitas Pembinaan Program Keluarga Sadar Gizi (KADARZI). Buletin Penelitian Sistem Kesehatan 2005

Jennifer Stewart-Glenn, MSN, FNP-BC, 2008. Knowledge, Perceptions, And Attitudes Of Managers, Coworkers, And Employed Breastfeeding Mothers. Aaohn journal. 2008 http://www.ebscohost.com 
liliweri Alo, 2011. Dasar-Dasar Komunikasi Kesehatan, Yogyakarta:Pustaka Pelajar.

Notoatmodjo, 2003. Pendidikan Dan Perilaku Kesehatan.Jakarta: Rineke Cipta Pendidikan Dan Promosi Kesehatan, Jakarta: Rineka Cipta 2007. Promosi Kesehatan dan Ilmu Perilaku. Jakarta: Rineka Cipta

Pudjiadi Solihin, 2005. Ilmu Gizi Klinis Pada Anak Edisi Ke Empat. Jakarta: FKUI

Soetjiningsih,1989. Tumbuh Kembang Anak. Jakarta: Kedokteran EGC
Sri, 2009. Pengaruh program Pendampingan Gizi Terhadap Pola Asuh, Kejadian Infeksi dan Status Gizi Balita Kurang energi Protein, Media Gizi Pangan, Vol VIII edisi 2

Sudarmanto, 2010. Pengaruh Pelatihan dengan Modul Pendampingan KMS Terhadap Pengetahuan dan Ketepatan dalam Interprestasi Hasil Penimbangan di Posyandu; 2010. etd.ugm.ac.id

Suharti, 2008. Pengaruh Penyuluhan dan Pelatihan Teknik Menyusui Terhadap Pengetahuan dan Keterampilan Ibu Nifas di RSD Raden Mattaher Jambi, ISSN 0854-8986 